\title{
Predicting the effects of freshwater diversions on juvenile brown shrimp growth and production: a Bayesian-based approach
}

\author{
Aaron T. Adamack ${ }^{1,5, *}$, Craig A. Stow ${ }^{2}$, Doran M. Mason ${ }^{2}$, Lawrence P. Rozas ${ }^{3}$, \\ Thomas J. Minello ${ }^{4}$ \\ ${ }^{1}$ Cooperative Institute for Limnology and Ecosystems Research, University of Michigan, Ann Arbor, Michigan 48108, USA \\ ${ }^{2}$ NOAA Great Lakes Environmental Research Laboratory, Ann Arbor, Michigan 48108, USA \\ ${ }^{3}$ NOAA National Marine Fisheries Service/SEFSC, Estuarine Habitats and Coastal Fisheries Center, Lafayette, Louisiana 70506, USA \\ ${ }^{4}$ NOAA National Marine Fisheries Service/SEFSC, Galveston Laboratory, Galveston, Texas 77551, USA
}

${ }^{5}$ Present address: Institute for Applied Ecology, University of Canberra, Canberra, ACT 2601, Australia

\begin{abstract}
Freshwater diversions from the Mississippi River may help restore coastal wetlands in Louisiana, but their implementation will alter temperature and salinity regimes, potentially affecting juvenile shrimp growth and production. We developed a bioenergetics model for brown shrimp Farfantepenaeus aztecus to investigate water temperature and salinity effects on brown shrimp growth. The model used a Bayesian framework that provided estimates of parameter and model uncertainty. Temperature affected shrimp metabolism, whereas salinity modified food availability. Mortality was modeled using a size-dependent function. We examined the effects of diversion timing (February, March, April and May), length $(2 \times 14$, as well as 30 and $60 \mathrm{~d})$, temperature change $\left(+1,0,-1,-5\right.$ and $\left.-10^{\circ} \mathrm{C}\right)$, initial salinity $(5,15,25)$, salinity during the diversion $(2$, $5,10,15,20$ and 25$)$ and prey biomass response time $(7,14$ and $28 \mathrm{~d}$ ) on juvenile brown shrimp production. Diversions during February and March had little effect on shrimp, but 30 and $60 \mathrm{~d}$ diversions starting in April and May often had large, negative effects on production. April and May diversions that dropped water temperature by $5^{\circ} \mathrm{C}$ or more could decrease juvenile brown shrimp production by 40 to $60 \%$ compared with the baseline, no diversion scenarios. Whether changes in salinity had a positive or negative effect on brown shrimp production depended on the initial salinity of the scenario. Longer diversions and slower prey response times extended the duration brown shrimp were exposed to either the positive or negative effects of diversions, and this magnified the overall (positive or negative) effect on shrimp production. Limiting diversions to February and March when brown shrimp populations are not abundant would minimize negative effects on shrimp production, though managers will be constrained by the needs of other species such as oysters, as well as ecosystem considerations.
\end{abstract}

KEY WORDS: Farfantepenaeus aztecus - Restoration - Salt marsh · Freshwater diversion · Mississippi River · Louisiana

Resale or republication not permitted without written consent of the publisher

\section{INTRODUCTION}

Coastal Louisiana has experienced extensive land loss $\left(\sim 4900 \mathrm{~km}^{2}\right)$ since 1900 (Day et al. 2007) and is projected to continue losing land at a rate of $26.7 \mathrm{~km}^{2}$ $\mathrm{yr}^{-1}$ (US Army Corps of Engineers 2004). Causes for this loss include reductions in sediment supply because of dam and levee construction, coastal wetland subsidence, the construction of canals for oil and gas exploration, and global sea level rise (Turner 1997, 
Day et al. 2000, Blum \& Roberts 2009). In response, the US Congress and the State of Louisiana have developed plans (US Army Corps of Engineers 2004, Coastal Protection and Restoration Authority of Louisiana 2007) to restore coastal wetlands. These plans recommend implementing freshwater diversions and reintroductions of Mississippi River water to coastal wetlands at several locations throughout coastal Louisiana. Although these diversions may help coastal restoration efforts, their effect on commercially important shrimp species is unclear.

Brown shrimp Farfantepenaeus aztecus and white shrimp Litopenaeus setiferus are major contributors to Louisiana's commercial fisheries catch, with the annual value of shrimp landings being $\sim 55$ million and 101 million USD $\mathrm{yr}^{-1}$, respectively (NMFS Commercial Fisheries Statistics, www.st.nmfs.noaa.gov/ st1/commercial/index.html). The planned diversions will change the spatial and temporal patterns of temperature and salinity in coastal salt marshes, which both species inhabit during their postlarval and juvenile stages. Water temperature strongly affects the growth rates of postlarval and juvenile penaeid shrimp (e.g. Zein-Eldin \& Aldrich 1965, Zein-Eldin \& Griffith 1966), whereas the effects of salinity are less clear. Laboratory experiments by Zein-Eldin (1963) and Zein-Eldin \& Aldrich (1965) found that salinity had little effect on shrimp growth rates, but low salinity $(<5)$ in combination with low water temperatures $\left(<15^{\circ} \mathrm{C}\right)$ could result in higher mortality rates. More recently, Saoud \& Davis (2003) showed that brown shrimp growth rates (weight-specific growth rate $\left[g^{\prime}\right]=0.072 \mathrm{~d}^{-1}$ ) at salinities of 8 and 12 were significantly greater than growth rates at salinities of 2 and $4\left(g^{\prime}=0.054\right.$ and $0.057 \mathrm{~d}^{-1}$, respectively). Haas et al. (2001) used stepwise multiple regression and Bayesian model averaging to predict stage-specific abundances of brown shrimp and reported that salinity was not a predictor variable for the abundance of brown shrimp post-larval juveniles. However, salinity was a predictor variable for the abundance of adult brown shrimp. Growth experiments by Rozas \& Minello (2011) using field mesocosms suggested that salinity may indirectly affect shrimp growth rates through differences in prey availability, a factor that was not examined in Zein-Eldin (1963) and Zein-Eldin \& Aldrichs' (1965) laboratory experiments nor in Saoud \& Davis's (2003) experiment.

We developed a bioenergetics model for brown shrimp using a Bayesian approach to investigate the potential effects of freshwater diversions and reintroductions of Mississippi River water to coastal wetlands on juvenile brown shrimp growth and produc- tion. The bioenergetics model allowed us to explore the potential effects of changes in temperature and salinity (through changes in prey availability) caused by freshwater diversions on shrimp growth, and the Bayesian framework facilitated an assessment of the model's uncertainties. We focused on brown shrimp, as they recruit to coastal salt marshes from late February through mid-May (McTigue \& Zimmerman 1991, Rogers et al. 1993). This period coincides with the timing of peak flow in the Mississippi River, and the likely times when many future diversions and reintroductions will occur. Initial model simulations compared brown shrimp growth predictions with observed growth rates over a broad range of temperatures and salinities. A second set of simulations examined the effects of changes in temperature, salinity and prey availability (related to diversion timing and length) on juvenile brown shrimp growth. These simulations were then combined with a size-dependent mortality model to produce estimates of shrimp production.

\section{METHODS}

\section{Bioenergetics model}

We constructed a bioenergetics model for brown shrimp beginning with the 'Wisconsin' model (Hewett \& Johnson 1997). The 'Wisconsin' model uses a mass balance approach to estimate the growth of an individual ( $g$ shrimp d $\mathrm{d}^{-1}$ ):

$$
\frac{\mathrm{d} W}{\mathrm{~d} t}=\left[C-\left(M_{\mathrm{R}}+S\right)-(F+U)-G\right] \cdot C a l \cdot W
$$

where $W$ is shrimp weight $(\mathrm{g}), t$ is time $(\mathrm{d}), C$ is the specific consumption rate, $M_{\mathrm{R}}$ is the specific respiration rate, $S$ is the energy lost to specific dynamic action, $F$ is the specific egestion rate, $U$ is the specific excretion rate and $G$ is the specific gonadal production (all in units of $g$ prey $\mathrm{g}^{-1}$ shrimp $\mathrm{d}^{-1}$ ), and Cal is a caloric conversion factor used to convert prey biomass into shrimp biomass. We assumed that the value of $G$ was 0 as the modeled shrimp are in the postlarval and juvenile stages and thus are expending limited amounts of energy on reproduction. Specific consumption rate and specific respiration rate are functions of temperature. To quantify the uncertainty in the model parameters and predictions, we used a Bayesian framework (Berger 1985) to develop our model.

The Bayesian framework is based on the Bayes theorem: 


$$
\pi(\theta \mid y)=\frac{\pi(\theta) f(y \mid \theta)}{\int_{\theta} \pi(\theta) f(y \mid \theta) \mathrm{d} \theta}
$$

The interpretation of Bayes theorem is that prior information (from outside of the experiment), represented by the prior probability distribution, $\pi(\theta)$, is combined with new information from the experiment, represented by the likelihood function $f(y \mid \theta)$, to obtain updated information, represented by the posterior probability distribution $\pi(\theta \mid \mathrm{y})$. For most practical applications, the denominator on the right side of the equation is regarded as a scaling constant and is ignored. In our application, $\theta$ represents one or more model parameters with values that are unknown or only approximately known, and y represents experimental or observed data. The prior distribution reflects what is known about $\theta$ based on theoretical considerations or previous relevant information. If the value of $\theta$ is fairly well known, then $\pi(\theta)$ can be chosen to have a small variance. In the extreme case where $\theta$ is believed to be known exactly, then a fixed value is specified. Alternatively, if $\theta$ is not well-known, or if the researcher wants the estimated value of $\theta$ to be based only on the new data, then a non-informative prior distribution, one with a large variance, can be used.

To develop the bioenergetics model, we first reduced the number of parameters to be estimated by rearranging the bioenergetics equations and combining several constants into a single, unknown parameter. This was done because the mathematical structure of the model and the available data did not allow for the separate estimation of all model parameters. We expanded Eq. (1), substituting in the expressions from Table 1 for $S, F$ and $U$, giving:

$$
\begin{aligned}
\frac{\mathrm{d} W}{\mathrm{~d} t}= & \left\{C-\left[M_{R}+s \cdot(C-e \cdot C)\right]-[e \cdot C+u \cdot(C-e C)]\right\} . \\
& C a l \cdot W
\end{aligned}
$$

where $s$ is the proportion of assimilated energy lost to specific dynamic action, $u$ is the proportion of assimilated energy lost to excretion and $e$ is the proportion of consumed energy that is not assimilated. Eq. (3) can be rearranged and simplified:

Table 1. Component expressions and parameters for the 'Wisconsin' bioenergetics model. Model equations were taken from Hanson et al. (1997). Initial values were based on sources provided in Table 2. Final values show the 2.5th, 50th and 97.5th percentiles of the posterior distribution for each of the parameters estimated using WinBugs ${ }^{\odot}$. Additionally, for parameters which

\begin{tabular}{|c|c|c|c|c|c|c|}
\hline \multirow[t]{2}{*}{ Parameter } & \multirow[t]{2}{*}{ Expression } & \multirow[t]{2}{*}{ Units } & \multirow[t]{2}{*}{$\begin{array}{l}\text { Initial } \\
\text { value }\end{array}$} & \multicolumn{3}{|c|}{$\begin{array}{l}\text { Final value } \\
\text { (percentile) }\end{array}$} \\
\hline & & & & 2.5 th & 50 th & 97.5 th \\
\hline Consumption $(C)$ & $\rho \cdot C_{\max }$ & g prey $\mathrm{g}^{-1}$ shrimp $\mathrm{d}^{-1}$ & & & & \\
\hline$\rho$ & & Proportion & n/a & & & \\
\hline$C_{\max }$ & $C A \cdot W^{C B} \cdot f(T)$ & g prey $\mathrm{g}^{-1}$ shrimp $\mathrm{d}^{-1}$ & & & & \\
\hline$C A$ & & g prey $\mathrm{g}^{-1}$ shrimp $\mathrm{d}^{-1}$ & 0.38 & & & \\
\hline$C B$ & & Unitless & -0.109 & -0.13 & -0.11 & -0.093 \\
\hline$C Q$ & & Unitless & $1.65,2.5$ & 1.66 & 1.72 & 1.78 \\
\hline$T_{\mathrm{opt}}$ & $f(T)$ & ${ }^{\circ} \mathrm{C}$ & 32.0 & 31.8 & 32.0 & 32.2 \\
\hline$T_{\max }$ & & ${ }^{\circ} \mathrm{C}$ & $38.0,40.0$ & & 38.0 & \\
\hline$p$ & & & 2.0 & 0.66 & 0.70 & 0.75 \\
\hline Respiration $\left(M_{\mathrm{R}}\right)$ & $R A \cdot W^{R B} \cdot r(T) \cdot A C T \cdot O X Y$ & $\mathrm{~g} \mathrm{O}_{2} \mathrm{~g}^{-1}$ shrimp d $\mathrm{d}^{-1}$ & & & & \\
\hline$R A$ & & $\mathrm{~g} \mathrm{O}_{2} \mathrm{~g}^{-1}$ shrimp d $\mathrm{d}^{-1}$ & 0.0115 & & & \\
\hline$R B$ & & Unitless & -0.168 & & & \\
\hline$R Q$ & & Unitless & $1.65,2.5$ & & 1.65 & \\
\hline$T_{\mathrm{r}, \mathrm{opt}}$ & $r(T)$ & ${ }^{\circ} \mathrm{C}$ & 35.0 & 34.8 & 35.0 & 35.2 \\
\hline$T_{\mathrm{r}, \mathrm{max}}$ & & ${ }^{\circ} \mathrm{C}$ & 38,40 & & 40.0 & \\
\hline$A C T$ & & Proportion & 2 & & & \\
\hline$O X Y$ & & g prey $\mathrm{g}^{-1} \mathrm{O}_{2}$ & 5.4 & & & \\
\hline Egestion $(F)$ & $e \cdot C$ & 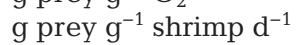 & & & & \\
\hline$e$ & & Proportion & $\mathrm{n} / \mathrm{a}$ & & & \\
\hline Excretion $(U)$ & $u \cdot(C-F)$ & g prey $\mathrm{g}^{-1}$ shrimp $\mathrm{d}^{-1}$ & & & & \\
\hline$u$ & & Proportion & $\mathrm{n} / \mathrm{a}$ & & & \\
\hline Specific dynamic action $(S)$ & $s \cdot(C-F)$ & g prey $\mathrm{g}^{-1}$ shrimp $\mathrm{d}^{-1}$ & & & & \\
\hline$S$ & & Proportion & $\mathrm{n} / \mathrm{a}$ & & & \\
\hline Caloric conversion factor ( $\mathrm{Cal}$ ) & & g shrimp $\mathrm{g}^{-1}$ prey & 0.5142 & & & \\
\hline Error term $\left(\sigma^{2}\right)$ & & & $\mathrm{n} / \mathrm{a}$ & 1.68 & 1.97 & 2.29 \\
\hline
\end{tabular}
had multiple initial values but did not have posterior distributions estimated using WinBugs ${ }^{\odot}$, the initial value selected for use in model simulations was listed as the 50th percentile under the final value 


$$
\frac{\mathrm{d} W}{\mathrm{~d} t}=\left[C \cdot(1-s+s e-e-u+u e)-M_{\mathrm{R}}\right] \cdot C a l \cdot W
$$

The contents within the brackets being multiplied by consumption consisted solely of constants and, therefore, they were combined into a single constant parameter, $p$ :

$$
\frac{\mathrm{d} W}{\mathrm{~d} t}=\left[p \cdot C-M_{\mathrm{R}}\right] \cdot C a l \cdot W
$$

We then expanded the consumption term (Table 1) in Eq. (5) and combined the constant $\rho$, proportion of maximum consumption realized, with the parameter $p$. Making these changes, we were able to reduce the number of parameters that needed to be estimated from 15 to 11. As a final step, we added an error term $(\varepsilon)$ to the model to account for model uncertainty. We chose to use a normal, additive error term with a mean of 0 and estimated the variance of the error term using WinBUGS ${ }^{\odot}$ (Lunn et al. 2000). The expanded model that was fit using a Bayesian framework was:

$$
\begin{aligned}
\frac{\mathrm{d} W}{\mathrm{~d} t}= & {\left[p \cdot C A \cdot W^{C B} \cdot f(T)-R A \cdot W^{R B} \cdot A C T \cdot r(T) \cdot O X Y\right] . } \\
& C a l \cdot W+\varepsilon
\end{aligned}
$$

where $C A$ is the intercept of the allometric mass function, $C B$ is the slope of the allometric mass function, $f(T)$ is the temperature-dependence function for consumption, $R A$ is the intercept of the allometric mass function for respiration, $R B$ is the slope of the allometric mass function for respiration, $A C T$ is the activity multiplier, $r(T)$ is the temperature-dependence function for respiration, $O X Y$ is the oxycaloric coefficient and Cal is the caloric conversion factor. The 2 temperature-dependence functions are based upon a temperature-dependence function for warm-water species developed by Kitchell et al. (1977). The function rises slowly to a peak with a value of 1 at the optimum temperature $\left(T_{\text {opt }}\right)$ and then declines to 0 at the maximum temperature $\left(T_{\max }\right)$. The slopes of the functions are determined by the parameters $C Q$ and $R Q$, which are analogous to a $Q_{10}$ parameter that determines how quickly the function increases for temperatures below the optimum temperature (Table 1). Model parameters in Eq. (6) were determined using a combination of literature values (Table 2) and estimates obtained using the Bayesian model-fitting framework on field observations and experimental data.

Field and experimental observations included growth rates of brown shrimp at known water temperatures. Field data were from caging experiments in coastal Louisiana and Texas (Rozas \& Minello 2009, 2011, L. P. Rozas \& T. J. Minello unpubl. data).
Data consisted of shrimp lengths and weights collected at the beginning and end of the field experiments. Initial weights were estimated using lengthweight relationships that were developed for each experiment using the lengths and weights of shrimp that were collected during each experiment (Rozas \& Minello 2009). Weight-specific growth rates, relative to the geometric mean weight of the shrimp during the experiment, were estimated using the equation:

$$
g^{\prime}=\frac{\left(\frac{W_{f}-W_{i}}{t_{l}}\right)}{\sqrt{W_{f} \cdot W_{i}}}
$$

where $g^{\prime}$ is the weight-specific growth rate (g growth $\mathrm{g}^{-1}$ shrimp d $\mathrm{d}^{-1}$ ), $W_{f}$ is the final weight, $W_{\mathrm{i}}$ is the initial weight and $t_{1}$ is the duration of the experiment (d). Daily water temperature was determined by taking the mean of hourly temperatures recorded during the experiments. Data from laboratory studies were taken from Zein-Eldin \& Aldrich (1965) and ZeinEldin \& Griffith (1966). Weight-specific growth rates were estimated using Eq. (7). Individual growth rates were not available from these studies, thus we estimated growth rates from groups of individuals. The completed data set consisted of 326 records and included shrimp ranging in size from 9.4 to $60.0 \mathrm{~mm}$ total length (TL) living in water temperatures from 11 to $35^{\circ} \mathrm{C}$ and salinities from 2 to 35 .

The Bayesian model fitting framework used a combination of Eq. (6), literature values and the weightspecific growth rates from field and experimental observations to fit the bioenergetics models. As several parameters in Eq. (6) were highly correlated, we took an iterative approach to estimate parameter values by fixing some parameter values at a value within their range of literature values and estimated the rest, conditional on the assigned values of the fixed parameters and the weight-specific growth rates from field and experimental observations. The parameters that were allowed to vary in a prior round of model fitting were then fixed at their estimated values while other parameters were allowed to vary. We repeated this process until there was no improvement in the model precision, which was defined as the inverse of the model variance. During initial rounds of parameter fitting, we observed that the values of several parameters for which we had direct measurements from brown shrimp or closely related species changed little or not at all. Thus, for later rounds of model fitting, we chose to permanently fix those parameters using reported values. The remaining parameters $(C B, C Q, C T O, p$ and $R T O)$ were estimated using $\mathrm{WinBugs}^{\circledR}{ }^{\circledR}$, and these estimates 
Table 2. Estimation methods and data sources for initial values of bioenergetics model parameters

\begin{tabular}{|c|c|}
\hline Growth component & Description and source \\
\hline $\begin{array}{l}\text { Allometric consumption } \\
\text { parameters }(C A \text { and } C B)\end{array}$ & $\begin{array}{l}C A \text { and } C B \text { were based on a modified version of the relationship between body weight and } \\
\text { maximum meal size }\left(M M ; \mathrm{g} \mathrm{h}^{-1} \text { ) for southern brown shrimp Penaeus subtilis developed by }\right. \\
\text { Nunes \& Parsons }(2000) \text {. The original relationship was } M M=0.0931 W^{0.62} \text {. This relationship } \\
\text { was modified to give a daily weight-specific maximum consumption rate (g prey } \mathrm{g}^{-1} \text { shrimp } \\
\left.\mathrm{d}^{-1}\right) M M_{\mathrm{ws}}=2.2344 W^{-0.38} \text {. CA was initially set to } 2.2344 \text { and } C B \text { was set to }-0.38 \text {. }\end{array}$ \\
\hline$Q_{10}(C Q$ and $R Q)$ & $\begin{array}{l}\text { Initial values for } C Q \text { and } R Q \text { were based upon } Q_{10} \text { values of } 1.59 \text { to } 1.71 \text { that were determined } \\
\text { from oxygen consumption rates of } 3.7 \text { and } 6.8 \mathrm{~g} \text { brown shrimp (Bishop et al. 1980), growth- } \\
\text { rate-derived } Q_{10} \text { values of } 0.60 \text { and } 4.95 \text { measured for Penaeus vannamei by Wyban et al. } \\
\text { (1995) and } C Q \text { values of } 2.5 \text { used by Haas et al. ( } 2004 \text { ) and Roth et al. (2008). } C Q \text { and } R Q \text { were } \\
\text { both initially allowed to vary freely, but their values, particularly } R Q \text {, changed little from the } \\
\text { range of values reported by Bishop et al. (1980). After the initial rounds of model fitting, } R Q \\
\text { was fixed at } 1.65 \text { while } C Q \text { remained free to vary. }\end{array}$ \\
\hline $\begin{array}{l}\text { Standard respiration } \\
(R A, R B)\end{array}$ & $\begin{array}{l}R A \text { and } R B \text { were estimated by fitting the function } R A \cdot W^{R B} \text { to white shrimp and brown } \\
\text { shrimp respiration rates reported in the literature (Alcaraz et al. } 1999 \text {, Bishop et al. 1980, Rosas } \\
\text { et al. } 1995 \text { a, Rosas et al. 1995b) as described by Alcaraz et al. } 1999 \text { and Zein-Eldin \& Klima } \\
1965 \text { for shrimp with weights between } 0.027 \text { and } 37.57 \mathrm{~g} \text {. }\end{array}$ \\
\hline $\begin{array}{l}\text { Optimum temperature } \\
(C T O, R T O)\end{array}$ & $\begin{array}{l}C T O \text { and } R T O \text { were initially set to } 32^{\circ} \mathrm{C} \text { as laboratory experiments by Zein-Eldin \& Aldrich } \\
\text { (1965) found shrimp had the highest growth rates at temperature between } 30 \text { and } 32.5^{\circ} \mathrm{C} \text {. } \\
\text { Previous models for brown shrimp developed by Haas et al. (2004) and Roth et al. (2008) set } \\
\text { CTO to } 32^{\circ} \mathrm{C} \text {. }\end{array}$ \\
\hline $\begin{array}{l}\text { Maximum temperature } \\
\left(T_{\max }, T_{\mathrm{r}, \max }\right)\end{array}$ & $\begin{array}{l}\text { Initial values for the maximum temperature for brown shrimp consumption and respiration } \\
\text { were based upon values from Re et al. (2005) and from Haas et al. (2004). Re et al. (2005) } \\
\text { examined the effect of the temperature and salinity to which brown shrimp were acclimatized } \\
\text { on their critical thermal maxima }\left(C T_{\max }\right) . C T_{\max } \text { was found to range between } 36.5 \text { and } 42.7 \text {, } \\
\text { with shrimp acclimatized to higher temperatures having higher } C T_{\max } \text {. Salinity was found to } \\
\text { have little effect on } C T_{\max } \text {. Haas et al. (2004) used a value of } 40^{\circ} \mathrm{C} \text { for the maximum tempera- } \\
\text { ture for brown shrimp growth. }\end{array}$ \\
\hline $\begin{array}{l}\text { Activity multiplier on } \\
\text { respiration }(A C T)\end{array}$ & $\begin{array}{l}\text { Dall (1986) showed that shrimp metabolic rates at night, when shrimp were most active, } \\
\text { were more than } 3 \text { times their metabolic rates during the day, when shrimp are primarily } \\
\text { resting. Assuming that days were split equally between day and night ( } 12 \mathrm{~h}: 12 \mathrm{~h} \text { ), the average } \\
\text { activity multiplier would be } \sim 2 \text {. }\end{array}$ \\
\hline Composite term $(p)$ & $\begin{array}{l}p \text { was a composite term that covered several model parameters }(e, u, s \text { and } \rho \text { ) that were } \\
\text { proportions. We therefore arbitrarily set the initial value of } p \text { to } 1.0 \text { and used a non-informative } \\
\text { prior distribution (e.g. large variance) for the Bayesian model-fitting process. }\end{array}$ \\
\hline $\begin{array}{l}\text { Caloric density of } \\
\text { shrimp }\end{array}$ & $\begin{array}{l}\text { McCawley (2003) determined shrimp caloric density using bomb calorimetry. Brown shrimp } \\
\text { were found to have a density of } 1166.86 \text { calories } \mathrm{g}^{-1} \text { shrimp. }\end{array}$ \\
\hline Caloric density of prey & $\begin{array}{l}\text { Based on the reports of shrimp prey types, we estimated that brown shrimp prey had a caloric } \\
\text { density of } \sim 600 \text { calories } \mathrm{g}^{-1} \text { prey based on the caloric density of zooplankton (Luo \& Brandt } \\
\text { 1993, McCawley 2003). }\end{array}$ \\
\hline $\begin{array}{l}\text { Oxycalorific coefficient } \\
(O X Y)\end{array}$ & The oxycaloric coefficient was set to $13.56 \mathrm{~kJ} \mathrm{~g}^{-1} \mathrm{O}_{2}$. \\
\hline
\end{tabular}

(Table 1) were compared with literature values for related species to confirm that they were reasonable.

\section{Salinity effects}

Field observations suggest that brown shrimp growth rates may be a function of salinity, manifested through salinity-dependent prey availability (Rozas \& Minello 2011). Thus, we indirectly added a simplistic salinity effect on prey availability to the bioenergetics model by developing a collective response function that acted as a multiplier to the consumption term in the model. The first part of the function determined the amount of prey available to shrimp as a function of salinity. Data for developing the salinity-prey availability function were from replicate sediment cores collected at each of 4 sites along a salinity gradient $(2.1,4.5,16.9$ and 19.7) in Barataria Bay during May 2007 (Rozas \& Minello 2011). The biomass of annelids and small crustaceans was determined separately for each core, and then the 2 biomasses were combined to give a single estimate of prey biomass. We used the software TableCurve ${ }^{\odot}$ 
(Aspires Software International) to fit a non-linear function relating prey biomass to the site salinity (Fig. 1A). Montagna et al. (2002, their Fig. 5B) and Zimmerman et al. (1990) report infaunal distribution data supporting the shape of this curve.

The second part of the function determined shrimp growth rate as a function of prey availability. Shrimp (Crangon spp.) feeding is known to follow either a type II or type III functional response (Taylor \& Collie 2003, Olmi \& Lipcius 1991), and our growth curve (Fig. 1B) appeared to follow the pattern of a type II functional response. The growth response function (e.g. Hastings 1997) was developed by fitting observed shrimp growth rates in field mesocosms (Rozas \& Minello 2011) with observed prey availability (Fig. 1B). The curve had a non-zero intercept as shrimp are able to feed and grow when the biomass of annelids and small crustaceans is zero by utilizing other food resources. This function assumed that shrimp feeding and growth rates would increase with increasing prey availability up to some maximum.
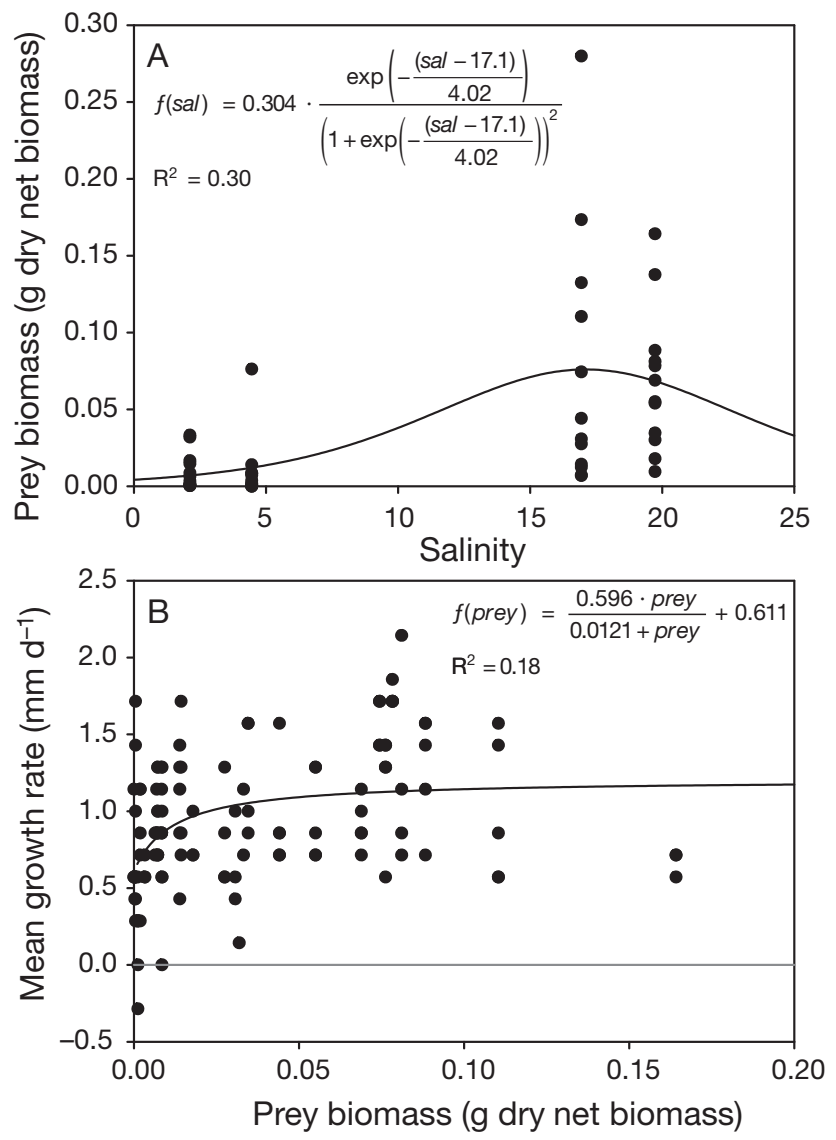

Fig. 1. (A) Combined biomass of annelids and crustaceans collected in cores during May 2007 (Rozas \& Minello 2011). Solid line shows the relationship that was fit between salinity and prey biomass using TableCurve ${ }^{\odot}$. (B) Type II numerical response relating brown shrimp growth rates to prey biomass
The fitted curve was then standardized using the asymptote of the curve, limiting the range of the function to between 0 and 1 . The final model takes the form:

$$
\begin{aligned}
\frac{\mathrm{d} W}{\mathrm{~d} t}= & {\left[\left(f_{\text {prey }}(\text { salinity }) \cdot p \cdot C A \cdot W^{B C} \cdot f(T)\right)-\right.} \\
& \left.\left(R A \cdot W^{R B} \cdot A C T \cdot r(T) \cdot O X Y\right)\right] \cdot C_{f}+\varepsilon
\end{aligned}
$$

where $f_{\text {prey }}$ (salinity) is the multiplier from the collective response function.

\section{Simulations}

We ran 2 sets of simulations. The first set (fixed condition scenario) was used to evaluate model performance by first simulating shrimp growth for a range of fixed temperatures and salinities and then comparing the predicted growth rates with observed growth rates from field and laboratory studies. The second set (freshwater diversion scenario) examined how different components of a diversion (e.g. timing, duration, magnitude of temperature and salinity change, and prey response time) would affect shrimp production during a 'typical' year. All combinations of changes in diversion timing, duration and magnitude of temperature and salinity change and prey response time were simulated allowing us to determine how a diversion would affect shrimp production across the likely range of water temperatures and salinities during diversions.

For both sets of simulations, the initial size of postlarval shrimp was $15 \mathrm{~mm}$ TL. Shrimp lengths $(L ; \mathrm{mm}$ TL) were converted to wet weights (g) using the length-weight relationship (unpublished data from Rozas \& Minello 2009):

$$
W=10.0^{(-5.129+\log (L) \cdot 3.013)}
$$

Each modeled shrimp in the 2 sets of simulations was randomly assigned a set of correlated bioenergetics parameters $\left(C B, C Q, C T O, p, R T O\right.$ and $\sigma^{2}$; see Tables 1 and 2 for descriptions) drawn from a list of $\sim 29000$ sets of parameters generated by WinBUGS ${ }^{\odot}$ from the final model. The model error variance, $\sigma^{2}$, was used to generate a random deviate from the distribution $N\left(0, \sigma^{2}\right)$, which was used to simulate model uncertainty. Preliminary model runs, which included an estimate of the model error drawn from the distribution $N\left(0, \sigma^{2}\right)$, resulted in a number of shrimp growing at rates that were unrealistically high ( $>4 \mathrm{~mm} \mathrm{~d}^{-1}$; the fastest reported growth rate for brown shrimp was $3.3 \mathrm{~mm} \mathrm{~d}^{-1}$; Table 3) during the peak months of growth. Further examination of those results showed 
that unrealistically high growth rates were due to the model error term. Therefore, we modified our error term by restricting it to deviates that were within \pm 2 standard deviations of the mean. Using this modified error term in the model, median growth rates during March and April, the months of peak brown shrimp recruitment, ranged from 0.6 to $1.4 \mathrm{~mm} \mathrm{~d}^{-1}$, which is comparable to the range of growth rates typically reported for brown shrimp (Table 3), whereas the maximum growth rate of $3.07 \mathrm{~mm} \mathrm{~d}^{-1}$ was less than the fastest reported growth rate of $3.3 \mathrm{~mm} \mathrm{~d}^{-1}$.

\section{Fixed condition scenario}

Shrimp growth was simulated using all combinations of the fixed temperatures $(5,10,15,20,25,30$, 35 and $37^{\circ} \mathrm{C}$ ) and salinities $(2,5,10,15,20,25$ and 30). For each simulation, the growth of 1000 individual shrimp was tracked for $365 \mathrm{~d}$ or until each individual had reached $75 \mathrm{~mm}$ TL, whichever came first. The weight-specific growth rates of individual simulated shrimp were determined for 3 size categories of shrimp (15-25, 35-45 and 50-60 mm); these size categories reflect the range of sizes available in the observed shrimp growth rate data. Simulated and observed shrimp growth rates were then compared to evaluate model fit.
Freshwater diversion scenario

For the freshwater diversion scenarios, we examined 1800 combinations of initial site salinity (3 sites), diversion timing ( 3 to 4 diversion periods) and duration (3 lengths), temperature (5 temperature drops) and salinity change ( 2 to 6 salinity drops) during diversions, and prey response times to changes in salinity (3 response times). Coastal marshes generally have a salinity gradient that ranges from freshwater (salinity 0) to saline (salinity $\sim 30$ ). We simulated 3 sites across the salinity gradient: an oligohaline site ( salinity $=5$ ), a mesohaline site (salinity = 15), and a euhaline site (salinity $=25$ ). Brown shrimp postlarvae enter coastal estuaries throughout the year (White \& Boudreaux 1977), with peak recruitment occurring between February and April (Gaidry \& White 1973, White \& Boudreaux 1977). Mississippi River water flow peaks between March and June; thus, we examined the effects of freshwater diversions between February and May. There are numerous potential diversion schemes that could be implemented by managers. We restricted our simulations of diversion duration to 3 potential plans. The first 2 plans (30 and $60 \mathrm{~d}$ diversions) operated in a manner similar to that of diversions currently operating in Louisiana, with the diversions being open continuously for lengthy periods of time (see, for example, Fig. 2 in

Table 3. Brown shrimp growth rates from published and unpublished sources

\begin{tabular}{|lcl|}
\hline & Growth rate $\left(\mathrm{mm} \mathrm{d}^{-1}\right)$ & \\
\hline Statistic & 1.4 & Sein-Eldin \& Aldrich (1965) \\
Mean & $<1.0$ & St. Amant et al. (1966) \\
Mean at $<20^{\circ} \mathrm{C}$ & $<1.5$ & Wheeler (1969) \\
Mean at $<25^{\circ} \mathrm{C}$ & 1.0 & Parrack (1979) \\
Growth rate estimated from von Bertalanffy & 1.2 & \\
growth curve for 1- to 2-month-old male shrimp & & \\
Growth rate estimated from von Bertalanffy & 1.3 & \\
growth curve for 1- to 2-month-old female shrimp & & \\
Mean & 0.77 & White (1975), White \& Boudreaux (1977), as reported \\
& & by Lassuy (1983) \\
Range & $0.5-0.9$ & Knudsen et al. (1977) \\
Maximum & 3.3 & Ringo (1965, as reported by Lassuy (1983) \\
Range of mean rates & $0.8-1.0$ & Minello \& Zimmerman (1991) \\
Overall means & $0.2-0.5$ & Whaley (1997) \\
Experiment 1 - range & $0.14-3.00$ & Unpublished data from Rozas \& Minello (2009) \\
Experiment 1 - mean & 1.60 & \\
Experiment 2 - range & $0.14-2.43$ & \\
Experiment 2 - mean & 1.17 & \\
Mean & 1.4 & Fry et al. (2003) \\
Range & $0-2.00$ & L. P. Rozas \& T. J. Minello (unpubl. data) - April 2006 \\
Mean & 0.97 & \\
Range & $-0.14-1.43$ & L. P. Rozas \& T. J. Minello (unpubl. data) - May 2006 \\
Mean & 0.63 & Unpublished data from Rozas \& Minello (2011) \\
Range & $-0.29-2.43$ & \\
Overall mean & 1.07 & \\
\hline
\end{tabular}


Day et al. 2003). For our simulations, the continuous diversions started on the first of a month and ended 30 or 60 d later. Thirty-day diversions were simulated for February, March, April and May whereas $60 \mathrm{~d}$ diversions were simulated for February-March, March-April and April-May. The third diversion plan $(2 \times 14$ d) was developed to roughly mimic the pattern of operation used in the PULSES program (Day et al. 2003). During the PULSES program, the Caernarvon diversion was operated at maximum capacity for short periods of time $(\sim 14 \mathrm{~d})$ resulting in high rates of overland flow, increased sediment deposition in marshes, and increased nutrient removal from river water. In this plan, two $14 \mathrm{~d}$ continuous diversions were initiated a month apart. The first diversion started on the first of a month, and the second diversion began on the first of the following month. The two 14 d diversions were simulated for FebruaryMarch, March-April and April-May.

When a freshwater diversion was activated in a model simulation, it caused water temperature and salinity to instantly drop by the specified values for the diversion. The impact of the change in salinity was moderated by the response time of shrimp prey to changes in salinity (described below). At the end of the diversion, temperature and salinity instantly returned to their non-diversion levels; however, the salinity effects on shrimp prey continued for several days (number of days dependent on prey response time) after the end of the diversion.

Baseline daily water temperature was determined using a temperature function (Fig. 2) that was fitted to $7 \mathrm{yr}$ of temperature data from Barataria Bay at station DCPBA03 (obtained from the Louisiana Department of Natural Resources' Strategic Online Natural Resources Information System, http:// sonris-www.dnr.state.la.us/). This station was selected because of its location within the estuary and the completeness of the data record. A comparison of predicted water temperatures with water temperatures from experiments conducted during April and May of multiple years in coastal Louisiana and Texas (Rozas \& Minello 2009, L. P. Rozas \& T. J. Minello unpubl. data) suggested that predicted daily water temperatures during April and May were $\sim 4^{\circ} \mathrm{C}$ cooler than observed water temperatures. This inconsistency was likely due to a combination of differences in sampling locations (monitoring stations sampled deeper, faster-moving water, whereas temperature during the field experiments was measured in shallow water near the marsh edge where shrimp typically occur) and interannual differences in water temperature. To account for this difference, we added $4^{\circ} \mathrm{C}$ to predicted water temperatures.

The addition of cool water from the Mississippi River by freshwater diversions may modify temperature regimes in salt marshes. To estimate the potential temperature differential between the Mississippi River and salt marshes, we compared approximately $5 \mathrm{yr}$ of daily water temperatures from a monitoring station in the Mississippi River at Baton Rouge (USGS 07374000) with temperatures from multiple Louisiana DNR monitoring stations located throughout the Barataria estuary (DCPBA03, DCPBA04, DCPBA05, DCPBA06, DCPBA07 and DCPBA08). Water in the Mississippi River was at most $10^{\circ} \mathrm{C}$ colder than water in the Barataria estuary during the winter, and at most $1^{\circ} \mathrm{C}$ warmer during the summer (Fig. 2). Based on those observed temperature differences, we simulated the effects of $0,1,2,5$ and $10^{\circ} \mathrm{C}$

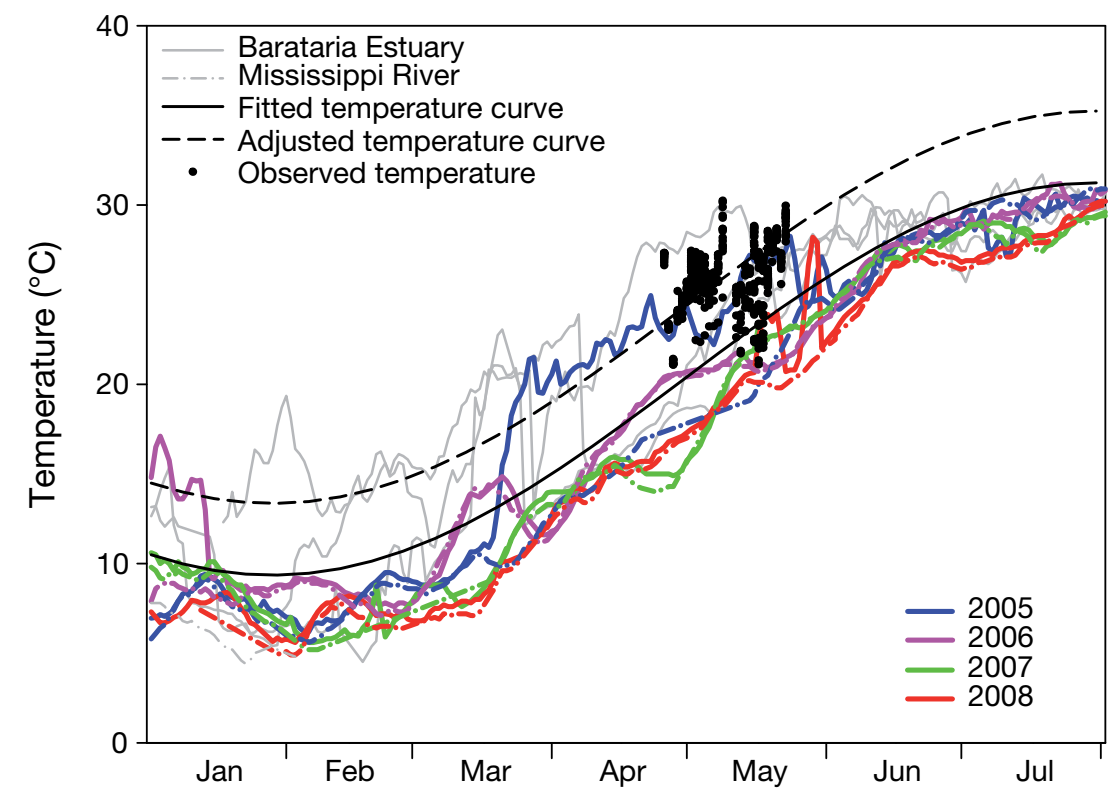

Fig. 2. Observed (2002-2004, solid gray lines; 2005-2008, solid colored lines) and predicted (solid black line) water temperatures for Barataria Bay (only temperatures from station DCPBA03 are shown for clarity; trends in water temperatures were generally consistent across stations) and observed (2002-2004 and 2009, dashed gray line; 2005-2008, dashed colored lines) water temperatures for the Mississippi River at Baton Rouge. Temperature data (black circles) from caging experiments (2003, 2006 and 2007) carried out by Rozas \& Minello (2009, 2011, unpubl. data) suggested that the predicted water temperatures were lower than the temperatures experienced by brown shrimp in their field experiments. The fitted temperature curve was adjusted upwards (dashed black line) by $4^{\circ} \mathrm{C}$ to correct for this difference 
temperature drops, and a $1{ }^{\circ} \mathrm{C}$ increase during freshwater diversions.

Freshwater diversions alter the pattern of salinity in salt marshes through the physical displacement of saline water by freshwater. Diversions have the potential to completely displace saltwater (salinity $25)$, replacing it with water that is near fresh $(\sim 0)$. Brown shrimp typically have higher survival in waters with salinity $\geq 2$ (e.g. Zein-Eldin 1963, Saoud \& Davis 2003). Therefore, we set the salinity during the diversion to salinities of 2, 5 and then additional increments of 5 up to a site's initial salinity. As an example, for a site with an initial salinity of 15 , we simulated diversion salinities of 2, 5, 10 and 15 .

We assumed that benthic annelid and small crustacean population densities (potential prey for brown shrimp) would respond to the salinity change; however, prey response time was not known. To account for this uncertainty, we repeated model runs, using prey response times of 7, 14 and $28 \mathrm{~d}$. Prey response times were simulated by setting the daily salinity to the moving average salinity for 7, 14 and $28 \mathrm{~d}$ windows. The prey biomass available for shrimp to consume each day was determined using the function relating prey biomass to site salinity (see 'Methods: Salinity effects'), using the day's salinity as the site salinity.

Results of the bioenergetics model were combined with a simple size-dependent mortality model (described below) to simulate the production of $75-\mathrm{mm}-$ long juvenile shrimp under each of the diversion scenarios. Simulations ran from 1 January through 1 August with a daily time step. Shrimp were introduced to the simulations in weekly cohorts. The first cohort entered the simulation on 1 January and was followed by additional cohorts at $7 \mathrm{~d}$ intervals. To minimize computational constraints, yet still obtain a representative sample of the range of individual responses to the diversions by each cohort, we used super-individuals (Scheffer et al. 1995) to simulate the growth and survival of juvenile shrimp. Each cohort consisted of 1000 super-individuals, with each super-individual having a distinct set of correlated bioenergetics parameters drawn from the list of 29000 sets of correlated bioenergetics parameters (see 'Methods: Simulations'). These parameters were held constant across cohorts (e.g. individual 1 of cohort 1 had the same set of bioenergetics parameters and model variance parameter as individual 1 of cohorts $2,3,4, \ldots)$. In addition, each super-individual was given a worth, where worth was defined as the number of individuals within a super-individual. Each super-individual started with an initial worth of
100000 ; thus, each cohort simulated $10^{8}$ individuals and had a computational overhead equivalent to 1000 individuals. Daily growth was forced by daily water temperature and salinity.

For each diversion scenario, daily mortality for each model individual was determined using a simplified version of the mortality function for brown shrimp from Haas et al. (2004) that was originally derived from brown shrimp mortality data reported by Minello et al. (1989). The mortality function consists of a baseline mortality rate $\left(0.02 \mathrm{~d}^{-1}\right)$ multiplied by a size-dependent multiplier:

$$
M=0.02 \times 53.092 \cdot L^{-1.1163}
$$

where $M$ is the instantaneous mortality rate $\left(\mathrm{d}^{-1}\right)$ and $L$ is length $(\mathrm{mm})$. Mortality rates were not modified by changes in salinity. The size-dependent mortality function was applied to the worth of a super-individual using the equation:

$$
N_{t+1}=N_{t} \cdot e^{-M t}
$$

where $N_{t+1}$ is the worth of the super-individual at the beginning of the next time step and $N_{t}$ is the worth of the super-individual at the start of the current time step.

For each simulation, we tracked the growth of super-individuals from 15 to $75 \mathrm{~mm}$ total length (TL). We assumed that at $75 \mathrm{~mm}$, juvenile shrimp migrate to open bay waters where the effects of freshwater diversions were diminished. Although cohorts were added to the model on a weekly basis from 1 January through 1 August, our analysis focused only on the production of shrimp cohorts that entered the model between mid-March (day-of-year [DOY] 79) and the end of May (DOY 151), the peak period of shrimp recruitment (Rogers et al. 1993, US Army Corps of Engineers \& Louisiana Department of Wildlife and Fisheries 1998). To summarize each simulation, we calculated the total biomass of $75 \mathrm{~mm}$ juvenile shrimp produced by cohorts entering the model between DOY 79 and 151. This was done by multiplying the final worth of each $75 \mathrm{~mm}$ super-individual by its weight and then summing across all superindividuals reaching $75 \mathrm{~mm}$ that entered the model during the peak recruitment period. To compare shrimp production across simulations, we standardized shrimp production using the biomass of $75 \mathrm{~mm}$ shrimp produced for the baseline scenarios (no freshwater diversion effects) at each of the 3 salinity sites $(5,15$ and 25$)$ using the equation:

standardized production $=\frac{\text { scenario production }}{\text { baseline production }}$ 
Standardizing shrimp production to the baseline (no diversion effect scenarios) allowed us to readily see the magnitude of the change in shrimp production for each scenario compared with the no diversion scenario.

\section{RESULTS}

\section{Fixed condition scenario}

Model to data comparison

Predicted brown shrimp growth rates from the fixed condition scenario compared favorably with the observed growth rates that were used to fit the model (Fig. 3, black circles). Eightyeight percent of observed growth rates were within the $95 \%$ credible region (interval between the 2.5th and 97.5th percentiles of predicted brown shrimp growth rates). The model was weakest (21 of 28 observations in the $95 \%$ credible region) at predicting the growth of small (15-25 mm) shrimp, underestimating their growth rates when water temperatures were near optimal for growth $\left(25-32^{\circ} \mathrm{C}\right)$ but salinity was low $(<10)$. For medium $(35-45 \mathrm{~mm})$ and large (50-60 $\mathrm{mm})$ shrimp, the model performed better with 63 of 68 and 67 of 75 observations, respectively, being within the $95 \%$ credible region. In contrast to small shrimp, medium and large shrimp with observed growth rates outside of the $95 \%$ credible region almost always grew at slower than predicted rates. We also compared predicted growth rates with growth rates from a semiindependent data set (Rozas \& Minello 2011), i.e. data used to fit the salinity function but not used to estimate model parameters for the bioenergetics model. The comparison improved with approximately $97 \%$ of observations falling within the $95 \%$ credible region (Fig. 3, red circles).

Shrimp growth rates from the baseline scenarios compared favorably with reported growth rates from the literature and with data on the temporal patterns of shrimp recruitment. Median growth rates of shrimp cohorts ranged from $0.68 \mathrm{~mm} \mathrm{~d}^{-1}$ in January to $1.08 \mathrm{~mm} \mathrm{~d}^{-1}$ for cohorts starting in May (Fig. 4), whereas the complete range of growth rates for individuals ranged from 0.05 to $3.97 \mathrm{~mm} \mathrm{~d}^{-1}$. With the exception of the very highest growth rates $(>3.0 \mathrm{~mm}$ $\mathrm{d}^{-1}$ ) experienced by the fastest-growing 1 to $3 \%$ of shrimp in cohorts during May, June and July, shrimp growth rates were within the range of rates reported for juvenile brown shrimp living along the coast of the northern Gulf of Mexico (Table 3). The temporal pattern in brown shrimp growth rates appeared to be reasonable, with growth being low between January and March (Fig. 4), when brown shrimp abundance in coastal salt marshes (Rogers \& Herke 1985, Rozas et al. 2007) and water temperatures (Fig. 2) are both 


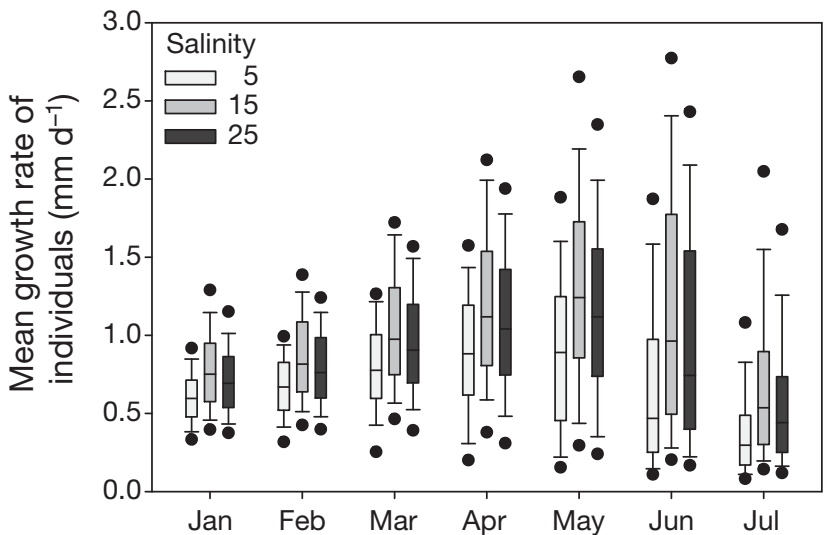

Fig. 4. Mean individual growth rates of all individuals from selected brown shrimp cohorts of the baseline (no diversion) scenario at the 3 salinity sites $(5,15$, and 25$)$. For each month, the cohort with the start date closest to the 15th of the month was selected. Mean individual growth rates were determined using the equation: mean growth rate $_{\mathrm{i}}=\left(L_{\mathrm{f}, \mathrm{i}}-L_{0, \mathrm{i}}\right) /\left(t_{\mathrm{f}, \mathrm{i}}-t_{0, \mathrm{i}}\right)$ where $L_{\mathrm{f}, \mathrm{i}}$ is the final length of an individual shrimp ( $75 \mathrm{~mm}$ or the length at the end of the simulation), $L_{0, \mathrm{i}}$ is the initial length of the shrimp $(15 \mathrm{~mm}), t_{\mathrm{t}, \mathrm{i}}$ is the last day of the simulation or the day that a shrimp individual reaches $75 \mathrm{~mm}$ total length, whichever comes first, and $t_{0, \mathrm{i}}$ is the date a shrimp's cohort enters the simulation. Black circles indicate the 5th and 95th percentiles, bar whiskers show the 10th and 90th percentiles, the box shows the 25th and 75th percentiles and

the solid line in the box shows the median growth rate

low. Shrimp growth rates increased during April and May when water temperatures and brown shrimp abundance in coastal salt marshes are high.

Fixed temperature and salinity effects

The pattern of shrimp growth was consistent across size classes (Fig. 3). Shrimp grew fastest at temperatures of 25 to $30^{\circ} \mathrm{C}$ and salinities of 10 to 25 . Small changes in water temperature caused large changes in shrimp growth rates over the temperature intervals of 20 to $25^{\circ} \mathrm{C}$ and 30 to $37^{\circ} \mathrm{C}$. Model uncertainty was greatest for the combination of temperatures and salinities that were associated with the highest growth rates and was lowest for the temperatures and salinities at which shrimp grew slowest.

\section{Freshwater diversion scenarios}

Timing and duration effects

The effect of freshwater diversions on brown shrimp production (Fig. 5) was greater for diversions later in spring (April and May) than earlier (February and March). Diversions during February (not shown) typi- cally had little or no effect on brown shrimp production ( $3 \%$ change in production or less), but could cause production to decline by $\sim 10 \%$ in extreme cases ( $60 \mathrm{~d}$ diversions, salinity dropping to 2 , and temperature dropping by $\left.10^{\circ} \mathrm{C}\right)$. Long diversion scenarios $(60 \mathrm{~d}$ diversions) magnified the effects of diversions. Sixty-day diversions had both the largest increase (with $1^{\circ} \mathrm{C}$ temperature increase) and the largest decrease (with $10^{\circ} \mathrm{C}$ temperature decrease) in shrimp production during each month that they were tested. In contrast, similar scenarios with short diversions $(2 \times 14 \mathrm{~d}$ and $30 \mathrm{~d})$ had more moderate effects on production (Fig. 5). The $2 \times$ $14 \mathrm{~d}$ diversions generally had greater effects (positive or negative) on brown shrimp production than $30 \mathrm{~d}$ diversions. This was likely because the second $14 \mathrm{~d}$ diversion happened in a later month when water was typically warmer (Fig. 2). However, on several occasions, particularly during April scenarios with initial salinities of 15 to 25 , diversion salinities of 2 to 10 and temperature drops of 5 to $10^{\circ} \mathrm{C}$, the interacting effects of diversion timing, temperature and salinity drops, and prey response times resulted in the $30 \mathrm{~d}$ diversions having a bigger effect on brown shrimp production than the $2 \times 14 \mathrm{~d}$ diversions.

The timing and duration of diversions interacted to affect relative shrimp production. Short diversions starting in March had only a limited $(<11 \%)$ effect on production, whereas $60 \mathrm{~d}$ diversions could result in production declines of up to $31 \%$ when water temperature dropped by $1^{\circ} \mathrm{C}$ or more (Fig. 5). If a $60 \mathrm{~d}$ diversion resulted in a $1^{\circ} \mathrm{C}$ temperature increase, brown shrimp production could increase by up to $14 \%$. During April, short diversions caused brown shrimp production to decrease by up to $31 \%$, roughly the equivalent of a $60 \mathrm{~d}$ diversion in March combined with temperature drops of 5 to $10^{\circ} \mathrm{C}$. Sixty-day diversions starting in April and $30 \mathrm{~d}$ diversions starting in May combined with temperature drops of $5^{\circ} \mathrm{C}$ or more both resulted in brown shrimp production being reduced by 60 and $40 \%$ or more, respectively. It is likely that much of the reduction in brown shrimp production for the April $60 \mathrm{~d}$ diversions was driven by slower growth in May, which subsequently increased cumulative mortality as $30 \mathrm{~d}$ diversions during April caused production to decline by $27 \%$ at most, whereas May $30 \mathrm{~d}$ diversions caused production to decline by up to $67 \%$.

\section{Temperature and salinity effects and their interactions}

Larger changes in temperature and salinity resulted in larger changes in brown shrimp produc- 


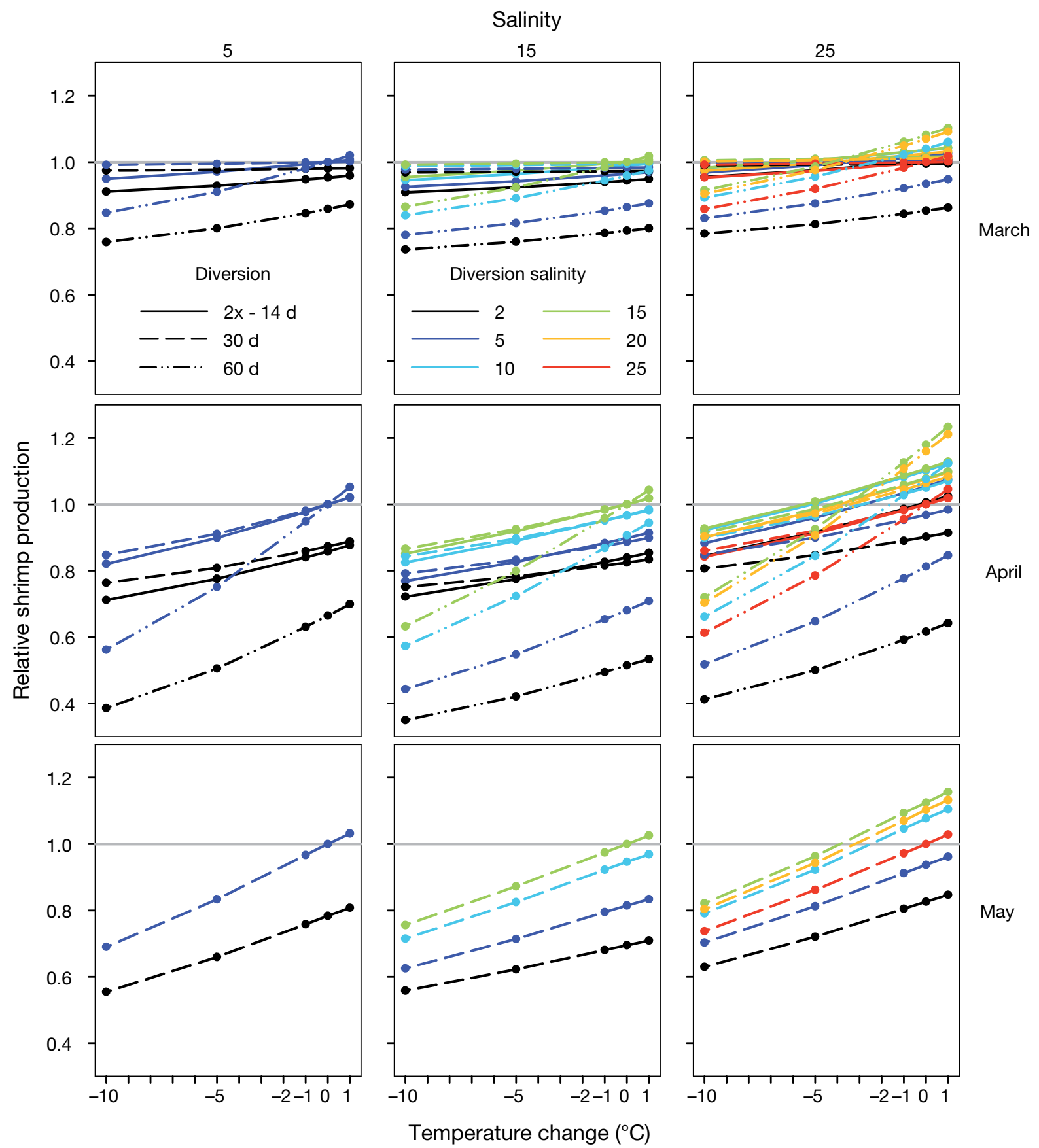

Fig. 5. Relative brown shrimp production for the freshwater diversion scenarios during March, April and May (rows) at sites with initial salinities of 5,15 and 25 (columns). Change in water temperature during freshwater diversions is shown on the $x$-axis and diversion length and salinity during the diversion are shown by line color and style (see key). Results for diversions during February are omitted as relative shrimp production varied little from the baseline scenario for each site. The gray reference line indicates the level of no change in relative shrimp production compared with the baseline scenario for each site

tion, but several factors could ameliorate or magnify these effects. For example, the largest changes in water temperature $\left(10^{\circ} \mathrm{C}\right.$ drop) and salinity (salinity dropping to 2) in April and May caused brown shrimp production to decline by up to $\sim 32 \%$ for short diversions and $63 \%$ for long diversions. The same magnitude of temperature and salinity change in February or March caused much weaker responses with reductions of less than $11 \%$ in February, regardless of diversion length, and by up to $11 \%$ for short diversions and $31 \%$ for long diversions in March. 
The effects of salinity changes during diversions were modified by the initial salinity of a scenario. For scenarios with an initial salinity of 5 or 15, a drop in salinity during diversions always resulted in a reduction in brown shrimp production (Fig. 5; salinity $=5$ or 15 all months). When the initial salinity was 25 , the reduction in salinity during a diversion frequently resulted in an increase in brown shrimp production, primarily when the change in temperature was small $\left(-1^{\circ} \mathrm{C} \leq \Delta T \leq 1^{\circ} \mathrm{C}\right)$, but also in some cases when temperature changes were larger (e.g. multiple versions of the $2 \times 14 \mathrm{~d}$ and $30 \mathrm{~d}$ diversions during March and April). Increased production in these scenarios was likely driven by an increase in prey availability when salinity dropped (Fig. 1A).

The magnitude of the effects of changes in prey response time on brown shrimp production was dependent on the scenario's initial salinity. For scenarios with initial salinities of 5 or 15, short ( $7 \mathrm{~d}$ ) and long (28 d) response times typically changed shrimp production by less than $1 \%$ (all percentages are absolute values) relative to the $14 \mathrm{~d}$ response time scenarios, although in a few scenarios the change could be as much as $5 \%$. For scenarios with an initial salinity of 25, short and long response times typically had a much larger effect, changing shrimp production by between 1 and $3 \%$ relative to the $14 \mathrm{~d}$ response time, and could cause changes of more than $16 \%$ in some scenarios (e.g. $2 \times 14$ d diversion starting in April, with salinity dropping to 2). In general, slower (28 d) prey response times resulted in larger reductions in shrimp production than faster prey response times at low initial salinities (5 and 15), but resulted in smaller reductions in production when initial salinity was high (25). Increasing prey response time extends the length of time shrimp are exposed to the beneficial or harmful effects of a diversion, and the diversion effects are therefore magnified.

\section{Scenario uncertainty}

Fixing model individual bioenergetics parameter sets across shrimp cohorts allowed us to determine total brown shrimp production over the course of a growing season for each parameter set. Distributions of total shrimp production across bioenergetics parameter sets could then be compared across freshwater diversion scenarios to determine whether there were differences in shrimp production among scenarios. Using the scenarios with an initial salinity of 5 and diversions starting in April as an example, we compared total brown shrimp production distributions across scenarios for temperature drops of 1 and $10^{\circ} \mathrm{C}$ (Fig. 6). The distributions of total brown shrimp production across scenarios with a $1^{\circ} \mathrm{C}$ temperature drop were somewhat similar, with the possible exception of the extreme case of a $60 \mathrm{~d}$ diversion and salinity dropping to 2, suggesting that there is not a clear difference in total shrimp production across salinity change and diversion duration scenarios (Fig. 6A). For the $10^{\circ} \mathrm{C}$ temperature drop scenarios, $2 \times 14 \mathrm{~d}$ and $30 \mathrm{~d}$ diversions with salinity dropping to 2 and 5 had similar patterns of total shrimp production, whereas $60 \mathrm{~d}$ diversions with salinity dropping to 2 and 5 had a reduced range of total shrimp production (Fig. 6B). These results suggest that differences in total shrimp production across scenarios with small temperature and salinity changes are too small to make inferences

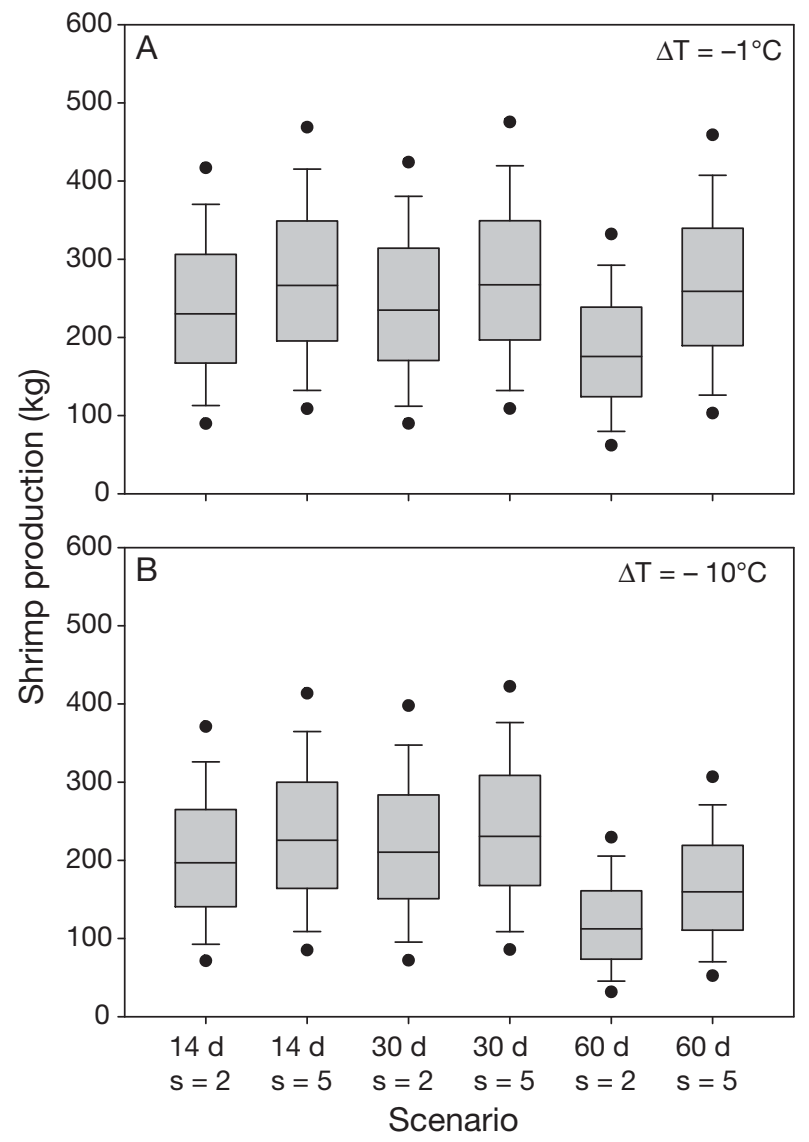

Fig. 6. Comparison of total production among diversion scenarios during April for a site with baseline salinity of 5. (A) Diversion with a $1^{\circ} \mathrm{C}$ temperature drop; (B) diversion with a $10^{\circ} \mathrm{C}$ temperature drop. Production values are for a modeled brown shrimp individual computed across cohorts. $14 \mathrm{~d}$ : $2 \times$ 14 d diversion length; $30 \mathrm{~d}: 30 \mathrm{~d}$ diversion length; $60 \mathrm{~d}: 60 \mathrm{~d}$ diversion length. $\mathrm{s}=2$ : diversion salinity of $2 ; \mathrm{s}=5$ : diversion salinity of 5 . Black circles indicate the 5 th and 95th percentiles, whiskers show the 10th and 90th percentiles of the distribution, the box shows the 25th and 75th percentiles, and the solid line in the box shows the median 
based on this model. For scenarios with larger changes in temperature and salinity, there was little difference between the short diversions $(2 \times 14 \mathrm{~d}$ and $30 \mathrm{~d}$ diversions) but somewhat larger differences between short diversions and the long (60 d) diversion; thus, our focus should be on differences between long and short diversion scenarios.

\section{DISCUSSION}

Freshwater diversions are a key tool for restoring coastal salt marshes (Day et al. 2007). Our model simulations, however, show that diversions have the potential to cause declines in brown shrimp growth and production, and these effects depend on the timing of the diversion and the magnitude of changes to estuarine water temperature and salinity. Nearly every diversion scenario we simulated resulted in reduced brown shrimp production. Exceptions were scenarios in which water temperatures were increased by the diversion, and scenarios in which a site had a high initial salinity (25) and the diversion only moderately reduced salinity (dropping salinity to 10 or 15). Over the long term, however, not implementing freshwater diversions may result in even larger reductions in shrimp production across a much broader spatial scale. Coastal Louisiana is losing coastal wetlands at a rapid rate (US Army Corps of Engineers 2004, Day et al. 2007), and changes in the spatial structure of coastal salt marshes may have profound effects on shrimp production. Roth et al. (2008) examined the effects of habitat fragmentation and inundation on the production of brown shrimp and reported a dome-shaped relationship between shrimp production and different measures of marsh condition. They found that initially, habitat fragmentation increases shrimp access to the marsh surface, which enhances their production, but over time the remaining habitat erodes away or subsides and is eliminated. By implementing freshwater diversions, it is hoped that the rate of marsh fragmentation in coastal Louisiana can be slowed or reversed (Day et al. 2009). However, it is not clear whether the sediment supply of the Mississippi River system is adequate to accomplish this goal (Blum \& Roberts 2009) or whether river diversions will perform as expected (e.g. Turner 2009).

Managers may potentially minimize declines in brown shrimp growth and production caused by a diversion using 2 operational methods. The first is to limit diversions to early spring (February and March), when brown shrimp numbers (Rogers \&
Herke 1985, Rozas et al. 2007) and growth rates (Fig. 4) are low. The second is to adjust the length and pattern (continuous vs. split) of water release by the diversion based upon the temperature difference between the freshwater source and the receiving basin, and the expected effects of the diversion on salinity patterns (e.g. the alternative scenarios for April and May in Fig. 5). Of the 2 methods, the first appears easier to implement, as managers could simply schedule water releases early in the year prior to the arrival of brown shrimp in the estuary. Implementing the second method would be more complicated. The initial spatial pattern of salinity within the estuary must be determined prior to any diversion so that managers can determine how the salinity pattern would be altered by increased inflows. If the salinity pattern is relatively simple (e.g. a predominantly saline marsh or a nearly fresh marsh), diversion flow rates could be determined from the volume of estuarine water that would be displaced by river water and by comparing temperatures in the 2 water masses. If the system is more complex and contains a number of salinity regions, however, the use of a hydrodynamics model may be necessary to predict how salinity and temperature patterns would be altered by the diversion. As a subsequent step, this model could then be applied to the predicted salinity and temperature patterns and used to identify diversion scenarios that minimize any adverse effects on shrimp.

The primary goal of constructing freshwater diversions in coastal Louisiana is to reconnect the Mississippi River with the deltaic plain (Day et al. 2009). As such, the pattern of flow from these diversions will be tied to the pattern of river flow. Mississippi River flow tends to be highest between February and June and peak in March and April. Brown shrimp are most abundant in marshes between March and June, with peak abundances in April or May (US Army Corps of Engineers \& Louisiana Department of Wildlife and Fisheries 1998). Thus, despite the relative ease of implementing the first method of minimizing the effects of diversions on shrimp, managers will likely need to consider using both methods because of interannual variability in the timing of peak river flow.

Our model results only apply to brown shrimp growth and production, and diversion effects on white shrimp may be quite different. White shrimp postlarvae recruit into Louisiana estuaries later in the spring, and juveniles are most abundant in summer and fall (Lindner \& Cook 1970, Turner \& Brody 1983). Historically, white shrimp dominated shrimp landings in Louisiana, and through the 1940s accounted 
for $95 \%$ of the catch (Condrey \& Fuller 1992). The appearance of brown shrimp and the end of dominance by white shrimp in Louisiana waters occurred in the late 1940s and early 1950s. A highly destructive Mississippi River flood in 1927 initiated widespread leveeing of the river, and this process continued until the 1940s when the entire Mississippi River was leveed (Conner \& Day 1987). Although other factors may have been involved, the decline in white shrimp landings was coincident with the decrease in natural flooding of estuaries and wetlands by the Mississippi River.

Using a Bayesian approach to estimate some of our model parameters (Table 1) produced reasonable results where comparisons could be readily made. Optimum temperatures for consumption (CTO) and respiration (RTO) were estimated to be 32.0 and $35.0^{\circ} \mathrm{C}$, respectively. The estimated optimum temperature for consumption was consistent with the finding of Zein-Eldin \& Aldrich (1965) that brown shrimp growth was maximal at 30 to $32.5^{\circ} \mathrm{C}$, and with 2 prior brown shrimp models, which used a value of $32^{\circ} \mathrm{C}$ (Haas et al. 2004, Roth et al. 2008). The estimated value of $R T O$ (Table 1) of $35.0^{\circ} \mathrm{C}$ is plausible, as brown shrimp are known to grow at or near their maximum rate between 32.5 and $35^{\circ} \mathrm{C}$ (Zein-Eldin \& Griffith 1966); however, the same study also observed that growth dropped substantially at $35^{\circ} \mathrm{C}$, and all individuals reared at that temperature died within $15 \mathrm{~d}$. It is likely that the actual value of $R T O$ is lower than $35^{\circ} \mathrm{C}$, and that the estimated value was a result of the model fitting process. Estimates of $C Q$ (more commonly called $Q_{10}$ ) range widely in the literature. Bishop et al. (1980) reported values of 1.59 to 1.65 for brown shrimp, Wyban et al. (1995) reported values of 0.60 to 4.95 depending on water temperature for Penaeus vannamei, and Haas et al. (2004) and Roth et al. (2008) both used a value of 2.5 for $C Q$ in their related shrimp models. Our $C Q$ estimate of 1.67 is clearly within the range of rates reported for brown shrimp. The estimated value of $C B(-0.11)$, one of the parameters used to define allometric consumption, was consistent with the assumption that weight-specific consumption would decrease as size increased (i.e. the sign was negative) and was similar in magnitude to, but smaller than, estimates of $C B$ for Penaeus subtilis $(-0.38$; Nunes \& Parsons 2000) and Farfantepenaeus paulensis $(-0.29$; Soares et al. 2005). It is difficult to compare the parameter $p$ with literature values, as it is a composite of 4 separate parameters $(s, e, u$ and $\rho)$ for which there is little information available. One simple check for the value of $p$ is that it should be between 0 and 1, as each of its components represented a proportion of consumption that is being used or lost because of biological actions. Our estimate of $p$ has a median value of 0.70 (Table 1), thus satisfying this initial check.

Model predictions of brown shrimp growth rates in relation to water temperature were consistent with the pattern of growth observed by Zein-Eldin and others in a pair of laboratory experiments. For both observed (Zein-Eldin \& Aldrich 1965, Zein-Eldin \& Griffith 1966) and modeled shrimp, growth rates were near zero at temperatures less than $15^{\circ} \mathrm{C}$ and more than 33 to $34^{\circ} \mathrm{C}$ and were at a maximum between $\sim 25$ and $\sim 32^{\circ} \mathrm{C}$. The increase in growth rate per unit of temperature was greatest for modeled shrimp between temperatures of 20 and $25^{\circ} \mathrm{C}$, whereas for observed shrimp, the largest increases were observed over the interval 17.5 to $25^{\circ} \mathrm{C}$. Modeled and observed brown shrimp growth rates from the same experiments were less consistent, however, when growth rates were compared over a range of salinities ( 2 to 30 for modeled shrimp, 2 to 35 for observed shrimp). Zein-Eldin \& Aldrich (1965, p. 215) found that 'salinity per se had little effect on either survival or growth, except at extreme temperatures'. In contrast, modeled shrimp had much lower growth rates ( 40 to $70 \%$ of the maximum median growth rate) at low salinities, even when temperatures were near optimal. This difference was due to differences in how shrimp were affected by low salinity in the simulations and the laboratory experiments. In the laboratory experiments (Zein-Eldin \& Aldrich 1965, Zein-Eldin \& Griffith 1966), the effects of salinity on growth were limited to any negative effects of osmoregulation on growth that low salinity may cause, as shrimp were fed brine shrimp (Artemia) in excess throughout the experiments. The result of those experiments was that salinity had no effect on growth. For modeled shrimp, the effects of salinity on growth were directly implemented through differences in prey availability, while the potential energetic costs of osmoregulation were ignored. In support of peak growth rates at mid-salinities in our model, Barrett \& Gillespie (1973) concluded that a salinity of approximately 19 was required for optimal brown shrimp production in Louisiana estuaries.

Our efforts shed some light on potential consequences of freshwater diversions on juvenile brown shrimp growth and production, but the precision and usefulness of our model predictions could be improved. Model uncertainty might be reduced if we were able to refit the model using observed growth rates for larger shrimp ( $\geq 35 \mathrm{~mm}$ ) from a wider range of temperatures. Most of the observed growth rates 
for larger brown shrimp came from a relatively narrow band of water temperatures $\left(24\right.$ to $\left.27^{\circ} \mathrm{C}\right)$. This limits the model fitting process, as there is little information available to inform the model for regions outside this narrow temperature range.

We believe that this model would be more useful for managers if it were combined with hydrological models of estuaries where freshwater diversions might be used. Combining the 2 (brown shrimp and hydrological) models would make it possible to better account for the spatial aspects of freshwater diversions, including changes in the amount of habitat of varying quality available for shrimp production, and would allow us to quantitatively estimate the effect of a diversion on shrimp production through comparisons of total shrimp production in the estuary before and after the implementation of a diversion. Additionally, if we were to take a more spatially explicit approach, similar to that of Haas et al. (2004) and Roth et al. (2008), the model could better account for the effects of shrimp movement throughout the system in response to changes in temperature, salinity and flooding. Information on predator and prey interactions and how changes in salinity from a diversion may modify these interactions could also be used to improve the model. This approach may also allow us to examine how changes in prey and predator community composition and fluctuations in prey and predator populations affect shrimp distribution and shrimp growth and mortality rates.

For our study, we were able to develop a simple model of freshwater diversion effects on shrimp prey availability. Developing a similar model to examine the effects of freshwater diversions on shrimp predator populations and their effect on shrimp mortality rates is far more complex. As an example, nekton populations and community structure in the Breton Sound estuary did not change consistently as salinity varied because of a freshwater diversion (Piazza \& La Peyre 2011). Furthermore, it is not clear how changes in predator populations and nekton community structure would affect shrimp mortality rates. A reduction in overall nekton abundance may be expected to reduce shrimp mortality rates, but if that reduction is combined with a shift in species composition to species that preferentially prey on shrimp, mortality rates may actually increase. Moreover, higher predator populations may be associated with lower shrimp mortality rates when the diversion also increases access to the marsh surface, where emergent vegetation reduces the foraging efficiency of predators (e.g. Ruiz et al. 1993), and decreases the spatial overlap between individual shrimp and their predators. Resolving the effects of freshwater diversions on shrimp mortality rates will likely require intensive site-specific sampling efforts or combining hydrodynamic models with spatially explicit models of shrimp and their predators. The possibility of combining our model with existing hydrological models (e.g. Moffatt and Nichol Engineers 2000, Reyes et al. 2003) was investigated, but these models lacked a temperature component, which is a key driver of shrimp growth. Future efforts at constructing hydrological models for coastal estuaries should strongly consider including forecasts of water temperature, which would facilitate their integration with biological models.

A final area where model performance could be improved is the treatment of prey availability. The relationship between infaunal biomass and salinity used in our model (Fig. 1A) is a simplification based on limited data from the Barataria estuary. Benthic infaunal diversity, abundance and biomass can be highly variable in estuaries and are affected by salinity, hypoxia, sediment texture and organic content, and disturbance (Schöttler et al. 1990, Conlan 1994, Ritter \& Montagna 1999). Evidence for a peak in infaunal biomass at intermediate salinities (15 to 20) is inconsistent. Low diversity and abundance of infaunal polychaetes and crustaceans is commonly observed in low-salinity water and in areas where salinity is highly variable (Sanders et al. 1965, Mannino \& Montagna 1997, Hyland et al. 2004). Gaston \& Nasci (1988), Zimmerman et al. (1990) and Montagna et al. (2002) reported peak infaunal densities at intermediate salinities in estuaries of the Gulf of Mexico, but other studies in these estuaries (Mannino \& Montagna 1997, Rakocinski et al. 1997, Gaston et al. 1998) and in North Carolina (Tenore 1972) suggest that both infaunal diversity and abundance continue to increase with increasing salinity. If infaunal abundance does increase with salinity (or decrease more gradually from the peak shown in Fig. 1A), the effect on the results for the saline site (initial salinity $=25$ ) would be to reduce or eliminate the increase in brown shrimp production caused by moderate drops (to 10 or 15 ) in salinity and increase the reduction in shrimp production caused by large drops (to 2 or 5 ) in salinity.

Infaunal populations are also known to vary seasonally. Meiobenthos (Coull 1985) and macrobenthos (Whaley \& Minello 2002) reach maximum abundance in early spring before declining rapidly following the arrival of predators (McTigue \& Zimmerman 1998). Assuming that prey biomass does decline throughout the spring, this decline may worsen the effects on 
shrimp production from freshwater diversions during April and May through a further reduction in shrimp growth rates. A better understanding of the population dynamics of benthic infauna in estuaries and how these populations respond to freshwater inflows could be used to improve model performance.

\section{CONCLUSIONS}

A brown shrimp bioenergetics model developed to examine the effects of river diversions on shrimp growth and survival was corroborated using observed growth rates from the published literature. Model runs that examined shrimp response to variations in the timing and duration of simulated diversions showed that diversions occurring early in the year (February, March) and for relatively short durations ( $2 \times 14 \mathrm{~d}$ or $30 \mathrm{~d}$ ) have little effect on shrimp production. In contrast, both short and long diversions during April and May can potentially cause large declines in shrimp production. Diversions lasting $60 \mathrm{~d}$ that began in April or $30 \mathrm{~d}$ diversions in May show the largest negative effect on production, potentially causing declines of approximately 60 to $70 \%$ when salinity and temperature were both low. The timing of the diversion appeared to affect brown shrimp production much more than changes in salinity and temperature per se. Therefore, limiting diversions to February and March, when brown shrimp populations are relatively low in estuaries, would minimize any potential negative effects on shrimp production. Managers will be constrained, however, by the needs of other commercially important species such as oysters Crassostrea virginica (Chatry et al. 1983, La Peyre et al. 2003). To address these competing concerns, as well as to address the spatial component of freshwater diversions, we recommend combining our brown shrimp model, similar models for oysters and other species of interest in the region, and a hydrological model. Doing so would enhance the usefulness of the model developed here for resource managers.

Acknowledgements. Personnel from the NOAA Fisheries Service, Southeast Fisheries Science Center, Fishery Ecology Branch assisted in conducting the field growth experiments and processing the growth data used to develop the model. We thank T. Kramer for the preparation of a much improved version of Fig. 3. We acknowledge funding of this research project from the Northern Gulf Institute, Southeast Fisheries Science Center and the Great Lakes Environmental Research Laboratory. The findings and conclusions in this report are those of the authors and do not necessarily represent the views of NOAA. This is contribution number 1600 of the NOAA Great Lakes Environmental Research Laboratory.

\section{LITERATURE CITED}

Alcaraz G, Espinoza V, Venegas C (1999) Acute effect of ammonia and nitrite on respiration of Penaeus setiferus postlarvae under different oxygen levels. J World Aquac Soc 30:98-106

Barrett BB, Gillespie MC (1973) Primary factors which influence commercial shrimp production in coastal Louisiana. Louisiana Wildlife and Fisheries Commission Technical Bulletin 9, New Orleans, LA

Berger JO (1985) Statistical decision theory and Bayesian analysis. Springer, New York, NY

Bishop JM, Gosselink JG, Stone JH (1980) Oxygen consumption and hemolymph osmolality of brown shrimp, Penaeus aztecus. Fish Bull 78:741-757

Blum MD, Roberts HH (2009) Drowning of the Mississippi Delta due to insufficient sediment supply and global sealevel rise. Nat Geosci 2:488-491

Chatry M, Dugas RJ, Easley KA (1983) Optimum salinity regime for oyster production on Louisiana's state seed grounds. Contrib Mar Sci 26:81-94

Coastal Protection and Restoration Authority of Louisiana (2007) Integrated ecosystem restoration and hurricane protection: Louisiana's comprehensive master plan for a sustainable coast. CPRA, Baton Rouge, LA

Condrey RE, Fuller D (1992) The U.S. Gulf shrimp fishery. In: Glantz $\mathrm{MH}$ (ed) Climate variability, climate change and fisheries. Cambridge University Press, Cambridge, p 89-119

Conlan KE (1994) Amphipod crustaceans and environmental disturbance - a review. J Nat Hist 28:519-554

Conner WH, Day JW (1987) Description of basin. In: Conner WH, Day JW (eds) The ecology of Barataria Basin, Louisiana: an estuarine profile. US Fish Wildl Serv Biol Rep 85:1-7

> Coull BC (1985) Long-term variability of estuarine meiobenthos: an 11 year study. Mar Ecol Prog Ser 24:205-218

> Dall W (1986) Estimation of routine metabolic rate in a penaeid prawn, Penaeus esculentus Haswell. J Exp Mar Biol Ecol 96:57-74

> Day JW, Shaffer GP, Britsch LD, Reed DJ, Hawes SR, Cahoon D (2000) Pattern and process of land loss in the Mississippi Delta: a spatial and temporal analysis of wetland habitat change. Estuaries 23:425-438

Day JW, Ko JY, Cable J, Day JN and others (2003) PULSES: the importance of pulsed physical events for Louisiana floodplains and watershed management. In: Renard KG, McElroy SA, Gburek WJ, Canfield HE, Scott RL (eds) First Interagency Conference on Research in the Watersheds. US Dept of Agriculture, Tucson, AZ

> Day JW, Boesch DF, Clairain EJ, Kemp GP and others (2007) Restoration of the Mississippi Delta: lessons from Hurricanes Katrina and Rita. Science 315:1679-1684

Day JW, Cable J, Cowan JH, DeLaune R and others (2009) The impacts of pulsed re-introduction of river water on a Mississippi Delta coastal basin. J Coast Res 54:225-243

Fry B, Baltz DM, Benfield MC, Fleeger JW, Gace A, Haas HL, Quinones-Rivera ZJ (2003) Stable isotope indicators of movement and residency for brown shrimp (Farfantepenaeus aztecus) in coastal Louisiana marshscapes. 
Estuaries 26:82-97

Gaidry WJ III, White CJ (1973) Investigations of commercially important penaeid shrimp in Louisiana estuaries. Louisiana Wildlife and Fisheries Commission Technical Bulletin 8, New Orleans, LA

Gaston GR, Nasci JC (1988) Trophic structure of macrobenthic communities in the Calcasieu estuary, Louisiana. Estuaries 11:201-211

Gaston GR, Rakocinski CF, Brown SS, Cleveland CM (1998) Trophic function in estuaries: response of macrobenthos to natural and contaminant gradients. Mar Freshw Res 49:833-846

> Haas HL, Lamon EC III, Rose KA, Shaw RF (2001) Environmental and biological factors associated with stagespecific abundance of brown shrimp (Penaeus aztecus) in Louisiana: applying a new combination of statistical techniques to long-term monitoring data. Can J Fish Aquat Sci 58:2258-2270

Haas HL, Rose KA, Fry B, Minello TJ, Rozas LP (2004) Brown shrimp on the edge: linking habitat to survival using an individual-based simulation model. Ecol Appl 14:1232-1247

Hanson PC, Johnson TB, Schindler DE, Kitchell JF (1997) Fish bioenergetics 3.0. Technical Report Wiscu-T-97-001. University of Wisconsin Sea Grant Institute, Madison, WI

Hastings A (1997) Population biology: concepts and models. Springer, New York, NY

Hewett SW, Johnson BL (1997) A generalized bioenergetics model of fish growth for microcomputers. Technical Report Wiscu-SG-87-245, University of Wisconsin Sea Grant Institute, Madison, WI

Hyland JL, Balthis WL, Posey M, Hackney CT, Alphin T (2004) The soft-bottom macrobenthos of North Carolina estuaries. Estuaries 27:501-514

Kitchell JF, Stewart DJ, Weininger D (1977) Applications of a bioenergetics model to yellow perch (Perca flavenscens) and walleye (Stizostedion vitreum vitreum). J Fish Res Board Can 34:1922-1935

Knudsen EE, Herke WH, Mackler JM (1977) The growth rate of marked juvenile brown shrimp, Penaeus aztecus, in a semi-impounded Louisiana coastal marsh. Annu Proc Gulf Carib Fish Inst 29:144-159

La Peyre MK, Nickens AD, Volety AK, Tolley GS, La Peyre JF (2003) Environmental significance of freshets in reducing Perkinsus marinus infection in eastern oysters Crassostrea virginica: potential management applications. Mar Ecol Prog Ser 248:165-176

Lassuy DR (1983) Species profiles: life histories and environmental requirements (Gulf of Mexico): brown shrimp. US Fish and Wildlife Service, Division of Biological Services. FWS/OBS-82/11.1. US Army Corps of Engineers, TR EL82-4, Washington, DC

Lindner M, Cook H (1970) Synopsis of biological data on the white shrimp Penaeus setiferus (Linnaeus) 1767. FAO Fish Rep 4:1439-1469

> Lunn DJ, Thomas A, Best N, Spiegelhalter D (2000) WinBUGS - a Bayesian modeling framework: concepts, structure, and extensibility. Stat Comput 10:325-337

- Luo J, Brandt SB (1993) Bay anchovy Anchoa mitchilli production and consumption in mid-Chesapeake Bay based on a bioenergetics model and acoustic measures of fish abundance. Mar Ecol Prog Ser 98:223-236

Mannino A, Montagna PA (1997) Small-scale spatial variation of macrobenthic community structure. Estuaries 20: 159-173
McCawley JR (2003) Diet and prey demand of red snapper, Lutjanus campechanus, on Alabama artificial reefs. MS thesis, University of South Alabama, Mobile, AL

McTigue TA, Zimmerman RJ (1991) Carnivory vs. herbivory in juvenile Penaeus setiferus (Linnaeus) and Penaeus aztecus (Ives). J Exp Mar Biol Ecol 151:1-16

McTigue TA, Zimmerman RJ (1998) The use of infauna by juvenile Penaeus aztecus Ives and Penaeus setiferus (Linnaeus). Estuaries 21:160-175

Minello TJ, Zimmerman RJ, Martinez EX (1989) Mortality of young brown shrimp Penaeus aztecus in estuarine nurseries. Trans Am Fish Soc 118:693-708

Minello TJ, Zimmerman RJ (1991) The role of estuarine habitats in regulating growth and survival of juvenile penaeid shrimp. In: DeLoach P, Dougherty WJ, Davidson MA (eds) Frontiers in shrimp research. Elsevier Science Publishers, Amsterdam

Moffatt and Nichol Engineers (2000) Barataria Basin RMA2 numerical model review and analysis. Final report to Louisiana Department of Natural Resources, Baton Rouge, LA

> Montagna PA, Kalke RD, Ritter C (2002) Effect of restored freshwater inflow on macrofauna and meiofauna in upper Rincon Bayou, Texas, USA. Estuaries 25:1436-1447

> Nunes AJP, Parsons GJ (2000) Size-related feeding and gastric evacuation measurements for the southern brown shrimp Penaeus subtilis. Aquaculture 187:133-151

> Olmi EJ III, Lipcius RN (1991) Predation on postlarvae of the blue crab Callinectes sapidus Rathbun by sand shrimp Crangon septemspinosa Say and grass shrimp Palaemonetes pugio Holthuis. J Exp Mar Biol Ecol 151: 169-183

Parrack ML (1979) Aspects of brown shrimp, Penaeus aztecus, growth in the northern Gulf of Mexico. Fish Bull 76:827-833

- Piazza BP, La Peyre MK (2011) Nekton community response to a large-scale Mississippi River discharge: examining spatial and temporal response to river management. Estuar Coast Shelf Sci 91:379-387

Rakocinski CF, Brown SS, Gaston GR, Heard RW, Walker WW, Summers JK (1997) Macrobenthic responses to natural and contaminant-related gradients in northern Gulf of Mexico estuaries. Ecol Appl 7:1278-1298

Re AD, Diaz F, Sierra E, Rodríquez J, Perez E (2005) Effect of salinity and temperature on thermal tolerance of brown shrimp Farfantepenaeus aztecus (Ives) (Crustacea, Penaeidae). J Therm Biol 30:618-622

Reyes E, Lane R, Day JW (2003) Watershed analysis of pulsing freshwater events using landscape modeling in coastal Louisiana. In: Renard KG, McElroy SA, Gburek WJ, Canfield HE, Russell SL (eds) Proceedings of the First Interagency Conference on Research in the Watersheds. US Department of Agriculture, Agriculture Research Service, Benson, AZ

Ringo RD (1965) Dispersion and growth of young brown shrimp. US Fish Wildl Serv Circ 230:68-70

Ritter C, Montagna PA (1999) Seasonal hypoxia and models of benthic response in a Texas bay. Estuaries 22:7-20

Rogers BD, Herke WH (1985) Estuarine-dependent fish and crustacean movements and weir management. In: Bryan CF, Zwank PJ, Chabreck RH (eds) Fourth Coastal Marsh and Estuary Management Symposium. Louisiana State University, Baton Rouge, LA

Rogers BD, Shaw RF, Herke WH, Blanchet RH (1993) Recruitment of postlarval and juvenile brown shrimp 
(Penaeus aztecus Ives) from offshore to estuarine waters of the Northwestern Gulf of Mexico. Estuar Coast Shelf Sci 36:377-394

Rosas C, Bolongaro-Crevenna A, Sánchez A, Gaxiola G, Soto L, Escovar E (1995a) Role of digestive gland in the energetic metabolism of Penaeus setiferus. Biol Bull 189: 168-174

Rosas C, Sanchez A, Díaz E, Soto LA and others (1995b) Oxygen consumption and ammonia excretion of Penaeus setiferus, $P$. schmitti, $P$. duorarum and $P$. notialis postlarvae fed purified test diets: effect of protein level on substrate metabolism. Aquat Living Resour 8:161-169

Roth BM, Rose KA, Rozas LP, Minello TJ (2008) Relative influence of habitat fragmentation and inundation on brown shrimp Farfantepenaeus aztecus production in northern Gulf of Mexico salt marshes. Mar Ecol Prog Ser 359:185-202

Rozas LP, Minello TJ (2009) Using nekton growth as a metric for assessing habitat restoration by marsh terracing. Mar Ecol Prog Ser 394:179-193

Rozas LP, Minello TJ (2011) Penaeid shrimp growth rates vary along an estuarine salinity gradient: implications for managing river diversions. J Exp Mar Biol Ecol 397: 196-207

Rozas LP, Minello TJ, Zimmerman RJ, Caldwell P (2007) Nekton populations, long-term wetland loss, and the effect of recent habitat restoration in Galveston Bay, Texas, USA. Mar Ecol Prog Ser 344:119-130

Ruiz GM, Hines AH, Posey MH (1993) Shallow water as a refuge habitat for fish and crustaceans in non-vegetated estuaries: an example from Chesapeake Bay. Mar Ecol Prog Ser 99:1-16

Sanders HL, Mangelsdorf PC Jr, Hampson GR (1965) Salinity and faunal distribution in the Pocasset River, Massachusetts. Limnol Oceanogr 10:R216-R229

Saoud IP, Davis DA (2003) Salinity tolerance of brown shrimp Farfantepenaeus aztecus as it relates to postlarval and juvenile survival, distribution, and growth in estuaries. Estuaries 26:970-974

Scheffer M, Baveco JM, DeAngelis DL, Rose KA, Van Nes EH (1995) Super-individuals a simple solution for modeling large populations on an individual basis. Ecol Model 80:161-170

Schöttler U, Daniels D, Zapf K (1990) Influence of anoxia on adaptation of euryhaline polychaetes to hyposmotic conditions. Mar Biol 104:443-452

Soares R, Wasielesky W, Peixoto S, D'Incao F (2005) Food consumption and gastric emptying of Farfantepenaeus paulensis. Aquaculture 250:283-290

St. Amant LS, Broom JG, Ford TB (1966) Studies of the brown shrimp, Penaeus aztecus, in Barataria Bay, Louisiana, 1962-1965. Annu Proc Gulf Carib Fish Inst 18:1-17

Taylor DL, Collie JS (2003) Effect of temperature on the functional response and foraging behavior of the sand shrimp Crangon septemspinosa preying on juvenile winter flounder Pseudopleuronectes americanus. Mar Ecol Prog Ser 263:217-234

Editorial responsibility: Romuald Lipcius, Gloucester Point, Virginia, USA
Tenore KR (1972) Macrobenthos of the Pamico River Estuary, North Carolina. Ecol Monogr 42:51-69

- Turner RE (1997) Wetland loss in the Northern Gulf of Mexico: multiple working hypotheses. Estuaries 20:1-13

Turner RE (2009) Doubt and the values of an ignorancebased world view for restoration: coastal Louisiana wetlands. Estuaries Coasts 32:1054-1068

Turner RE, Brody MS (1983) Habitat suitability index models: Northern Gulf of Mexico brown shrimp and white shrimp. FWS/OBS-82/10.54. US Fish and Wildlife Service, Washington, DC

US Army Corps of Engineers (2004) Louisiana Coastal Area (LCA), Louisiana Ecosystem Restoration Study. US Army Corps of Engineers, New Orleans, LA

US Army Corps of Engineers \& Louisiana Department of Wildlife and Fisheries (1998) Caernarvon freshwater diversion structure biological monitoring program postconstruction report. Available at http://sonris-www.dnr. state.la.us/dnrservices/redirectUrl.jsp?dID=3903562

Whaley SD (1997) The effects of marsh edge and surface elevation on the distribution of salt marsh infauna and prey availability for nekton predators. MS thesis, Texas A \& M University, College Station, TX

Whaley SD, Minello TJ (2002) The distribution of benthic infauna of a Texas salt marsh in relation to the marsh edge. Wetlands 22:753-766

Wheeler RS (1969) Culture of penaeid shrimp in brackishwater ponds, 1966-67. Proc Southeast Assoc Game Fish Comm 22:387-391

White CJ (1975) Effects of 1973 river flood waters on brown shrimp in Louisiana estuaries. Louisiana Wildlife and Fisheries Commission Technical Bulletin 16, New Orleans, LA

White CJ, Boudreaux CJ (1977) Development of an areal management concept for gulf penaeid shrimp. Louisiana Wildlife and Fisheries Commission Technical Bulletin 22, New Orleans, LA

> Wyban J, Walsh WA, Godin DM (1995) Temperature effects on growth, feeding rate and feed conversion of the Pacific white shrimp (Penaeus vannamei). Aquaculture 138:267-278

Zein-Eldin ZP (1963) Effect of salinity on postlarval penaeid shrimp. Biol Bull 125:188-196

Zein-Eldin ZP, Aldrich DV (1965) Growth and survival of postlarval Penaeus aztecus under controlled conditions of temperature and salinity. Biol Bull 129:199-216

Zein-Eldin ZP, Griffith GW (1966) The effect of temperature upon the growth of laboratory-held postlarval Penaeus aztecus. Biol Bull 131:186-196

Zein-Eldin ZP, Klima EF (1965) Effects of injected biological stains on oxygen uptake by shrimp. Trans Am Fish Soc 94:277-278

Zimmerman RJ, Minello TJ, Castiglione MC, Smith DL (1990) Utilization of marsh and associated habitats along a salinity gradient in Galveston Bay. NOAA Tech Memo NMFS-SEFC-250. Available at http://galveston.ssp.nmfs. gov/publications/pdf/788.pdf

Submitted: April 15, 2010; Accepted: September 29, 2011 Proofs received from author(s): January 3, 2012 